Reprod. Nutr. Dévelop., 1980, 20 (1 B), 241-249.

\title{
Control of Sertoli and germ cell populations in the cock and sheep testes
}

par $M$. de REVIERS, Marie-Thérèse HOCHEREAU-de REVIERS *, M. R. BLANC*, J. P. BRILLARD, M. COUROT *, J. PELLETIER *

Station de Recherches Avicoles

* Station de Physiologie de la Reproduction

I.N.R.A., Nouzilly, 37380 Monnaie, France.

Summary. Sertoli celis are involved in the control of spermatogenesis. In adult animals, the Sertoli cell stocks, fixed before puberty, are highly correlated with those of the germ cells. Some factors influencing Sertoli cell stock formation have been analyzed :

1) Early hemicastration of impuberal animals showed that the proliferative activities of the Sertoli and the germ cells before puberty, rather than their initial numbers at birth, were the limiting factors of their final number in adult testis.

2) During testicular growth, LH and FSH levels were correlated to Sertoli cell stocks and to germ cell production.

3) The season of birth influenced the Sertoli cell stock formation in the ram. Daylength modified testicular development in the cockerel and the sheep.

4) Between-strain differences were more marked for the testis than for body growth in the cockerel. In the ram, Sertoli cell stocks were similar between half-brothers but significantly different between sires.

\section{Introduction.}

The Sertoli cells represent the permanent somatic cells of the seminiferous epithelium. Their total number per testis is established at puberty as mitosis ceases before their differentiation is finished (Steinberger and Steinberger, 1971 ; Nagy, 1972).

The morphological relationships between germinal and Sertoli cells (Fawcett, 1975), as well as the positive correlation between Sertoli cell stocks per testis and germ cell production (Hochereau-de Reviers and Courot, 1978), are indicative of their interactions.

In this paper, the formation of Sertoli cell stocks and germ cell production have been studied in the cock and ram testes to determine their controlling factors : initial number, endocrine environment during the prepuberal period, season, daylength and genetic origin of the animal. 


\section{Material and methods.}

Animals. - Lambs and rams : December or June-born lle-de-France (Idf) rams were submitted to the natural environment and hemicastrated as impuberal when 6 weeks old. They were compared to normal animals born at the same seasons.

All the animals were castrated during the sexual season, when they were 19 and 13 months old, respectively. December-born animals were bled once weekly till 80 days of age, i.e. around the age at which the Sertoli cell mitotic activity stops. The plasma were deep frozen until required for the hormone assays.

Adult Idf rams born either in the spring or the autumn were castrated during the sexual season (end of summer or beginning of autumn). 13-month old Romanov rams born in the spring were castrated during their second sexual season.

Cockerels : Hemicastration experiments were done in either the M55 strain (egg type) or the 199 strain (meat type). The influence of constant or increasing photoperiods was studied in growing cockerels of the M519 cross (egg type). All the cockerels were fed ad libifum, raised on the ground until 16 weeks of age and then individually caged. The temperature was controlled throughout the experiments (decreased from 32 to $20^{\circ} \mathrm{C}$ between hatching and 6 weeks of age, then kept at $20 \pm 3{ }^{\circ} \mathrm{C}$ ).

Histological analysis. - The total number of Sertoli cells per testis (TNSC) was determined according to Attal and Courot (1963). Round spermatids were evaluated similarly and their daily production (DSP) was calculated using either the seminiferous epithelium cycle duration in the ram (10.4 days, Ortavant, 1959) or the lifespan of round spermatids in the cock (2.5 days, de Reviers, 1968).

Hormonal assays. - The hormones were assayed using specific radioimmunoassays of ovine LH according to Pelletier et al. (1968) and of ovine FSH according to Blanc and Poirier (1979).

\section{Results.}

Hemicastration. - Hemicastration of either winter or summer-born impuberal 6-weeks old lambs resulted in a significant increase of testis weight (33 and 45 p. 100

TABLE 1

Effect of season of birth on testicular weight, Sertoli cell content and spermatid production of rams in their second sexual season, and on their impuberal plasma levels of LH and FSH

\begin{tabular}{|c|c|c|c|c|}
\hline \multirow[b]{2}{*}{ Month } & \multicolumn{2}{|c|}{ December } & \multicolumn{2}{|c|}{ June } \\
\hline & $\begin{array}{l}\text { Intact } \\
(n=8)\end{array}$ & $\begin{array}{l}\text { Hemicastrated } \\
\qquad(n=4)\end{array}$ & $\begin{array}{l}\text { Intact } \\
(n=4)\end{array}$ & $\begin{array}{c}\text { Hemicastrated } \\
(\mathrm{n}=5)\end{array}$ \\
\hline $\begin{array}{l}\text { Testis weight }(\mathrm{g}) \ldots \ldots \ldots \\
\text { TNSC } \times 10^{8} \ldots \ldots \ldots \ldots \\
\text { DSP } \times 10^{7} \ldots \ldots \ldots \ldots \\
\text { LH }(40 \text { to } 80 \text { days }) \ldots \ldots \ldots \\
\text { FSH }(40 \text { to } 80 \text { days }) \ldots \ldots \ldots\end{array}$ & $\begin{array}{l}235 \pm 13 \\
48.2 \pm 4.9 \\
301 \pm 14 \\
2.8 \pm 0.8 \\
0.8 \pm 0.1\end{array}$ & $\begin{array}{l}387 \pm 63 \\
73.5 \pm 4.7 \\
423 \pm 41 \\
5.3 \pm 1.3 \\
2.4 \pm 0.6\end{array}$ & $\begin{array}{c}268 \pm 35 \\
60.1 \pm 9.5 \\
437 \pm 61\end{array}$ & $\begin{array}{c}431 \pm 27 \\
72.4 \pm 8.3 \\
549 \pm 56\end{array}$ \\
\hline
\end{tabular}

Hemicastrated when 6 weeks old.

Castrated when 19 and 13 months old, respectively. 
respectively), total number of Sertoli cells per testis (TNSC) (52 and 20 p. 100 respectively) and daily production of round spermatids (DSP) (40 and 26 p. 100 respectively) during the sexual season (table 1).

These compensations were much more marked (100 p. 100) in cockerels (M55 strain) hemicastrated at 2 weeks of age (prepuberal stage). The compensatory hypertrophy of testis weight, TNSC and germ cells was completed within 6 weeks after surgery, and was maintained long after sexual maturity (fig. 1).

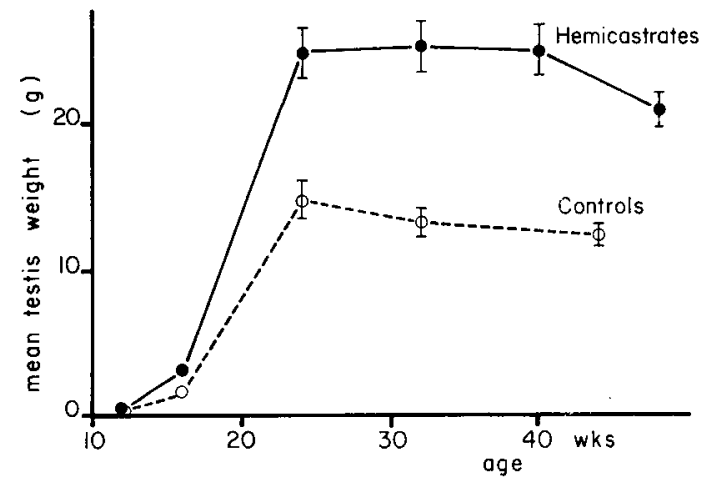

FIG. 1. - In cockerels hemicastrated at 2 weeks of age, the remaining testis fully compensates within 6 weeks affer surgery. This compensation is maintained until at least $\mathbf{4 0}$ weeks of age. For purposes of clarity, the curve for hemicastrates shows the mean weight of the remaining testis, while the control curve shows the mean weight of the two testes. In both cases, each point represents the mean weight $(\mathrm{m} \pm$ s.e. $\mathrm{m}$.) of 10 cockerels.

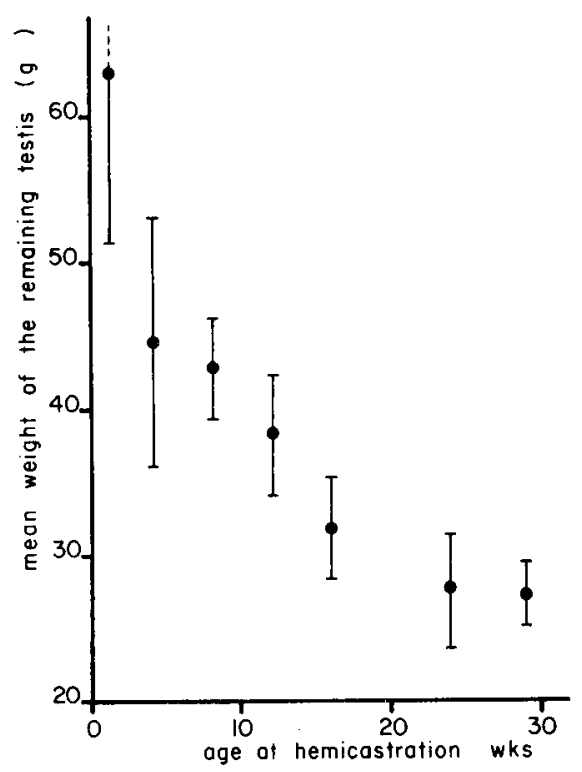

FIG. 2. - Variations of the mean weight of the remaining testis in 30-33 weeks old cockerels hemicastrated from 1 to 24 weeks of age. Each point is the mean of 8-10 tesles except for hemicastration at 1 week (3 testes) ( $m \pm$ s.e.m.). 
When hemicastration was done in ageing cockerels (199 strain), the compensations observed at 30-33 weeks of age in testis weight and in TNSC decreased as the age at hemicastration increased from 1 to 16 weeks (fig. 2). From 16 weeks onwards, there was no significant hypertrophy of the remaining testis. The adult testis weight, TNSC and DSP were highly significantly correlated $(0.85<r<0.95)$.

There were no correlations in either species between the weight of the testis removed at hemicastration and the weight of the remaining testis in the adult.

Endocrine status. - In growing lambs during the impuberal and prepuberal period, a temporary increase in the plasma $\mathrm{LH}$ and $\mathrm{FSH}$ levels in hemicastrates was observed as compared to control animals (table 1). In both groups of lambs, TNSC was correlated with the plasma levels of hormones (LH and TNSC $: r=0.69,0.10<\mathrm{P}<0.05 ; \mathrm{FSH}$ and TNSC $: r=0.69, \mathrm{P}=0.05 ;$ TNSC and $\mathrm{LH}+\mathrm{FSH}: \mathrm{r}=0.86, \mathrm{P}=0.01$ ).

Season and daylength.

1) In the normal postpuberal Idf rams of the previous experiment, there were significant differences in TNSC or DSP according the season of birth (spring or autumn) (table 1). The same differences were also found in larger groups of animals, but in those groups the correlations between TNSC and DSP was higher in spring-born $(r=0.67, n=24, P<0.05)$ than in autumn-born $(r=0.46, n=15,0.10<P<0.05)$ rams.

2) In the cockerels (M519 cross) the TNSC plateaued earlier but at a lower level under increasing photoperiods (8L/16D to $16 \mathrm{~L} / 8 \mathrm{D}:$ maximum $=286 \times 10^{6}$ at 16 weeks of age) than under constant daily photoperiods $(8 \mathrm{~L} / 16 \mathrm{D}$ or $16 \mathrm{~L} / 8 \mathrm{D}$ : maximum $=323$ or $352 \times 10^{6}$ at 24 weeks of age). DSP increased between 16 and 24 weeks of age but at different rates according to the light regime (table 2 ).

\section{TABLE 2}

Variations of testicular paramefers in M519 cockerels, aged 16 or 24 weeks, submitted to different daily photoperiods

\begin{tabular}{llccc}
\hline \multirow{2}{*}{ Photoperiods } & Parameter & \multicolumn{2}{c}{ Age of cockerels (weeks) } \\
\cline { 3 - 4 } & & 16 & 24 \\
\hline \multirow{3}{*}{ Constant (8L/16D) } & testis weight (g) & $1.4 \pm 0.6$ & $16.8 \pm 1.4$ \\
& TNSC $\times 10^{6}$ & $185 \pm 25$ & $323 \pm 30$ \\
& DSP $\times 10^{6}$ & $92 \pm 64$ & $1870 \pm 230$ \\
\hline \multirow{2}{*}{ Constant (16L/8D) } & MTW & $1.2 \pm 0.02$ & $19.5 \pm 1.8$ \\
& TNSC & $241 \pm 45$ & $352 \pm 36$ \\
& DSP & $34 \pm 17$ & $2670 \pm 319$ \\
\hline \multirow{2}{*}{ Increasing (8L to 16L) } & MTW & $12.6 \pm 2.3$ & $16.1 \pm 1.5$ \\
& TNSC & $286 \pm 55$ & $288 \pm 33$ \\
& DSP & $1620 \pm 310$ & $2160 \pm 240$ \\
\hline
\end{tabular}

Increasing photoperiods were used from 8 to 16 weeks of age $(-1-1 \mathrm{hr} /$ week) starting at $8 \mathrm{~L} / 16 \mathrm{D}$, and maintained. 
Genetic origin. - In adult Idf or Romanov spring-born rams examined at the same age (13 months) and season (autumn), there were between-breed differences for TNSC and DSP, Idf rams having the higher scores (table 3 ).

\section{TABLE 3}

Effect of breed (Romanov or Ile-de-France) on testis weight, Sertoli cell stock and round spermatid production of animals in their second sexual seoson

\begin{tabular}{lcc}
\hline & $\begin{array}{c}\text { Romanov } \\
n=4\end{array}$ & $\begin{array}{c}\text { lle-de-France } \\
n=4\end{array}$ \\
\hline Testis weight $(g) \ldots \ldots$ & $163 \pm 13.6$ & $268 \pm 35$ \\
TNSC $\left(\times 10^{8}\right) \ldots \ldots$ & $39.1 \pm 4$ & $60.1 \pm 9.5$ \\
$\operatorname{DSP}\left(\times 10^{7}\right) \ldots \ldots$ & $248 \pm 71$ & $437 \pm 61$ \\
\hline
\end{tabular}

During the sexual season, TNSC was roughly similar between half-brothers, from the same sire, but there were significant differences between sires (table 4). Four out of the 7 families were analysed for DSP variations and the same differences were observed (table 4).

\section{TABLE 4}

Variations in Sertoli cell stock and round spermatid production in different families of spring-born lle-de-France rams

\begin{tabular}{crccc}
\hline No of sire & $n$ & TNSC $\left(\times 10^{8}\right)$ & $n$ & DSP $\left(\times 10^{7}\right)$ \\
\hline A & 5 & $54 \pm 4$ & & $213 \pm 14$ \\
B & 6 & $55 \pm 2$ & 3 & $223 \pm 24$ \\
C & 7 & $59 \pm 7$ & 3 & $334 \pm 61$ \\
D & 10 & $65 \pm 4$ & 5 & $355 \pm 35$ \\
E & 3 & $82 \pm 13$ & & \\
F & 3 & $48 \pm 5$ & &
\end{tabular}

TNSC : $F=2,52$ df 7 and $33 \quad P<0,05$.

DSP : $F=4,43$ df 3 and $11 \quad P=0,05$.

TABLE 5

Comparison of festicular parameters of cockerels from either the 199 strain or the M519 cross roised under $16 \mathrm{~L} / 8 \mathrm{D}$

\begin{tabular}{clrrrr}
\hline Age (Weeks) & Parameter & & 16 & 24 \\
\hline \multirow{3}{*}{199 strain (Meat type) } & Testis weight & 4 & \pm & 2.0 & $25 \pm 2.0$ \\
& TNSC $\times 10^{6}$ & $345 \pm 10^{6}$ & 24 & $488 \pm 84$ \\
& DSP $\times 10^{6}$ & $288 \pm 151$ & $2880 \pm 210$ \\
\hline \multirow{3}{*}{ M519 cross (egg type) } & MTW & TNSC & $241 \pm \pm$ & 45 & $20 \pm 1.8$ \\
& DSP & $34 \pm 17$ & $2670 \pm 320$
\end{tabular}

( $m \pm$ s. e. $m ., n=5$ ). 
In the cockerel, there are also significant differences in TNSC and DSP in the I 99 strain and the M519 cross, irrespective of age (16 or 24 weeks) (table 5).

\section{Discussion.}

\section{Hemicastration.}

In spite of the removal of half of the initial stock of Sertoli and germ cells, the early hemicastrated cockerel observed at the adult stage had the same testicular weight as the combined weights of both testes in the controls of the same age, while the total number of Sertoli cells and round spermatids per animal did not significantly differ in the two groups. Furthermore, there is no correlation between the weight of the testis removed at hemicastration and the adult weight of the remaining testis in the cock, ram, rat or bull (Hochereau-de Reviers, unpublished data). Consequently, the development of the remaining festis does not depend on its weight (or number of Sertoli cells) at hemicastration. In the growing cockerel, as in the rat (Hochereau-de Reviers, 1975), the closer the age at hemicastration to that at which the Sertoli cell mitoses terminate, the less is the compensatory hypertrophy found in the remaining testis. Therefore, the adult TNSC and DSP are more related to the proliferative capabilities of the Sertoli and germ cells during growth than to their initial numbers at early hemicastration.

In seasonal breeders, however, there is compensatory hypertrophy of the remaining testis, even if hemicastration is performed during adulthood (duck : Benoit, 1930 ; sparrow : Farner ef al., 1970 ; badger : Canivenc and Relaxans, 1967 ; field vole : Martinet and Meunier, 1975). In the ram, this hypertrophy is no longer mediated by a proliferation of the Sertoli cells, whose number remains constant in the adult, but by an increased yield of spermatogenesis (Hochereau-de Reviers, Loir and Pelletier, 1976).

\section{Endocrine status.}

The formation of, and the variations in TNSC are partly controlled by gonadotrophins : in the prepuberal rat, TNSC decreases after hypophysectomy (Ortavant ef al., 1969), while it increases after the augmentation of plasma gonadotrophin levels induced by cyproterone treatment (Viguier-Martinez and Hochereau-de Reviers, 1977). In hemicastrated prepuberal rats, in which TNSC is increased, the plasma gonadotrophins also augment : LH shows a moderate increase (Ojeda and Ramirez, 1972) and FSH a marked one (Ojeda and Ramirez, 1972 ; Cunningham ef al., 1978). FSH could therefore play a prominent role in Sertoli cell proliferation in the rat. This hypothesis is reinforced by the fact that FSH promotes Sertoli cell mitoses in culture (Fritz ef al., 1978).

In the impuberal hypophysectomized lamb, the TNSC is maintained by LH given alone but not by FSH. This number however is enhanced by $\mathrm{LH}$ and FSH given together (Courot, 1971). In the normal, hemicastrated or unilaterally cryptorchid growing lamb, TNSC is correlated with plasma LH assay between 40 and 55 days (Hochereaude Reviers ef al., 1979).

Thus, in the rat and the ram, the main role is allocated to either FSH or LH according to the species. A synergism between these hormones also appears to be implicated in Sertoli cell proliferation which is gonadotrophin-dependent in mammals. 
Season and photoperiod.

The season of birth, possibly by increasing or decreasing photoperiods, influences the endocrine parameters in the lamb before puberty : mean plasma LH levels increase at a higher rate in lambs born in the spring than in those born in the autumn (Courot ef al., 1975). Furthermore, in lambs housed in conirolled-environment pens subjected to decreasing daylengths, a time-lag is observed in the $\mathrm{LH}$ and testosterone increases at the onset of sperm production and in the increment in testis diameter as compared to lambs submitted to increasing daylengths (Alberio, 1976). Mean plasma FSH levels up to the prepuberal age do not seem to be season-dependent (Blanc, unpublished data). In growing cockerels submitted to different light regimes, plasma LH levels also appeared to be different (Wilson and de Reviers, unpublished data).

\section{Genefical origin.}

Mean plasma LH levels have been shown to be breed-dependent up to puberiy (Carr and Land, 1975 ; Bindon and Turner, 1976 ; Blanc et al., 1975). The Romanov breed has higher plasma levels of both gonadotrophins than the lle-de-France breed ; however, it has the lowest TNSC. Thus, Sertoli cells ability to divide in response to high levels of gonadotropins might also be different. In cockerels of different genetic origins, a proportionality between body and testis weights is observed; the same relationship could also be involved in the differences found between Romanov and Ile-de-France rams.

\section{Conclusion.}

In adult animals, the sperm production is related to the Sertoli cell stock. Therefore the factors controlling its formation influence (at least partly) the sperm production, i. e. after hemicastration. The Sertoli cell mitoses are under gonadotrophin control. Variations of daylength during the prepuberal period can modify gonadotrophin levels and, consequently, the Sertoli cell stock. Genetic differences in these stocks could be explained either by variations in gonadotrophin levels or by changes in the sensitivity of the target cells to these gonadotrophins.

5e Réunion du groupe Développement I.N.R.A., Clermont-Ferrand/Theix, 17-18 mai 1979.

Acknowledgments. - We are grateful to Mrs. Christine Perreau and Messrs. J. C. Poitier and A. Caraty for their skilled technical assistance and to Dr. J. Williams for his help with the English translation. This work was carried out with the aid of DGRST grants (nos. 76-7-0047 and 74-7-0807) and with funds provided by the I.N.R.A. and the CNRS (A. I no. 1308).

Résumé. Les cellules de Sertoli sont impliquées dans le contrôle de la spermatogenèse. Chez les animaux adultes, les stocks de cellules de Sertoli, fixés avant la puberté, sont en corrélation élevée avec les stocks de cellules germinales. Quelques-uns des facteurs agissant sur la formation du stock de cellules de Sertoli sont analysés : 
1) L'hémicastration précoce d'animaux impubères montre que les quantités de cellules germinales et de Sertoli présentes dans le testicule adulte sont conditionnées par les capacités de prolifération de ces cellules avant la puberté plutôt que par leurs nombres à la naissance.

2) Vis-à-vis de cette prolifération, les niveaux de FSH et de $\mathrm{LH}$ pendant la période prépubertaire sont des facteurs importants.

3) La saison de naissance (Bélier) ainsi que la durée d'éclairement (Coq et Bélier) agissent sur la constitution des stocks de cellules de Sertoli.

4) Les stocks de cellules de Sertoli du Bélier, du même ordre de grandeur entre demi-frères issus du même père, sont par contre significativement différents suivant le père.

\section{Références}

ALBERIO R., 1976. Rôle de la photopériode dans le développement de la fonction de reproduction chez l'agneau lle-de-France de la naissance d̀ 21 mois. Th. 3e cycle Phys. Reprod., Paris.

ATTAL J., COUROT M., 1963. Développement testiculaire ef éfablissement de la spermatogenèse chez le taureau. Ann. Biol. anim. Biochim. Biophys., 3, 219-242.

BENOIT J., 1930. Castration unilatérale et hypertrophie compensatrice du testicule restant chez le coq et le canard. C. R. Soc. Biol., 104, 883-886.

BINDON B. M., TURNER H. N., 1976. Plasma LH of the prepuberal lamb : A possible early indicator of fecundity. J. Reprod. Fert., 39, 85-88.

BLANCM. R., POIRIER J. C., 1979. A new homologous radioimmunoassay for ovine follicle stimulating hormone : development and characterization. Ann. Biol. anim. Bioch. Biophys., 19, 1011-1026.

BLANC M. R., COUROT M., PELLETIER J., THIMONIER J., 1975, cited by THIMONIER J., 1975. Etude de la puberté et de la saison sexuelle chez les races prolifiques ef leurs croisements avec les races françaises. 1 res journées Rech. Ovine et Caprine, 18-87, ITOVIC ed. Paris.

BROWN N. L., BAYLE J. D., SCANES C. G., FOLLETT B. K., 1975. Chicken gonadotrophins : Their effects on the testis of immature and hypophysectomized japanese quail. Cell Tissue Res., 156, 499-520.

CANIVENC R., RELAXANS M. C., 1967. Résultats de l'hémicastration chez le blaireau européen mâle. C. R. Acod. Sci. Paris, 264, 2138-2140.

CARR W. R., LAND R. B., 1975. Plasma luteinizing hormone levels and testis diameters of ram lambs of different breeds. J. Reprod. Fert., 42, 325-333.

COUROT M., 1971. Etablissement de la spermatogenèse chez l'agneau (Ovis aries). Etude expérimentale de son contrôle gonodotrope : importance des cellules de la lignée serfolienne. Th. Dr. ès Sci., Paris, C.N.R.S. A.O. 6317 .

COUROT M., DE REVIERS M. M., PELLETIER J., 1975. Variations in pituitary and blood LH during puberty in the male lamb. Relation to time of birth. Ann. Biol. anim. Bioch. Biophys., 15, 509-516.

CUNNINGHAM G. R., TINDALL D. J., HUCKINS C., MEANS A. R., 1978. Mechanisms for the testicular hypertrophy which follows hemicastration. Endocrinology, 102, 16-23.

FARNER D. S., MORTON H. L., FOLLETT B. K., 1970. The limitation of rate of photoperiodically induced testicular growth in the white-crowned sparrow Zonotrichio leucophrys gambelii. The effect of hemicastration. Arch. Anat., 51, 190-196.

FAWCETT D. W., 1975. Ultrastructure and function of the Sertoli cell. In GREEP R. O., HAMILTON D. W., Handbook of Physiology : Endocrinology, 5, 21-55. Am. Physiol. Soc. Publ.

FRITZ B., LOUIS B. G., TUNG P. S., DORRINGTON J., 1978. Action of hormones on Sertoli cells during maturation. Ann. Biol. anim. Bioch. Biophys., 18, 555-563.

HOCHEREAU-DE REVIERS M. T., 1975. Augmentation de l'efficacité de la spermatogenèse par l'hémicastration chez le rał et le bélier. Ann. Biol. anim. Bioch. Biophys., 15, 621-631.

HOCHEREAU-DE REVIERS M. T., COUROT M., 1978. Sertoli cells and development of seminiferous epithelium. Ann. Biol. anim. Bioch. Biophys., 18, 573-583.

HOCHEREAU-DE REVIERS M. T., LOIR M., PELLETIER J., 1976. Seasonal variations in the response of the testis and LH levels to hemicastration of adult rams. J. Reprod. Ferf., 46, 206-209.

HOCHEREAU-DE REVIERS M. T., BLANC M. R., COUROT M., GARNIER D. H., PELLETIER J., PO:RIER J. C., 1980. Hormonal profiles and testicular parameters in the lamb., 237-247.

- In E. and A. STEINBERGER. Testicular development, structure and functions. Raven Press Publ. N. Y. 
MARTINET L., MEUNIER M., 1975. Rôle de la durée quotidienne d'éclairement sur la réponse après hémicastration du testicule restant chez le campagnol des champs (Microfus arvalis). Ann. Biol. anim. Bioch. Biophys., 15, 607-609.

NAGY F., 1972. Cell division kinetics and DNA synthesis in the immature Sertoli cells of the rat testis. J. Reprod. Fert., 28, 389-399.

OJEDA S. R., RAMIREZ V. D., 1972. Plasma level of LH and FSH in maturing rats : Response to hemigonadectomy. Endocrinology, 90, 466-472.

ORTAVANT R., 1959. Déroulement el durée du cycle spermatogénétique chez le bélier. Ann. Zoofech., 8, 183-244, 271-321.

ORTAVANT R., COUROT M., DE REVIERS M. M., 1969. Activités spécifiques de différentes FSH et LH sur le testicule de mammifères. In : La spécificité zoologique des hormones hypophysaires ef leurs activités. Coll, int. C.N.R.S., 177, 369-379, C.N.R.S., Paris.

PELLETIER J., KANN G., DOLAIS J., ROSSELIN G., 1968. Dosage radioimmunologique de l'hormone lutéinisante plasmatique chez le mouton. Mise au point de la technique de dosage. C. R. Acad. Sci. Paris, Série D, 226, 2291-2294.

REVIERS M. (de), 1968. Détermination de la durée des processus spermatogénétiques chez le coq à l'aide de Thymidine tritiée. V/e Congr. int. Reprod. anim. Insém. artif., Paris, 1, 183-185.

STEINBERGER A., STEINBERGER E., 1971. Replication pattern of Sertoli cells in maturing rat testis in vivo and in organ culfure. Biol. Reprod., 4, 84-87.

VIGUIER-MARTINEZ M. C., HOCHEREAU-DE REVIERS M. T., 1977. Comparative actions of cyproterone and cyproterone acetate on pituitary and plasma gonadotrophin levels, the male genital tract and spermatogenesis in the growing rat. Ann. Biol. anim. Bioch. Biophys., 17, 1069-1076. 